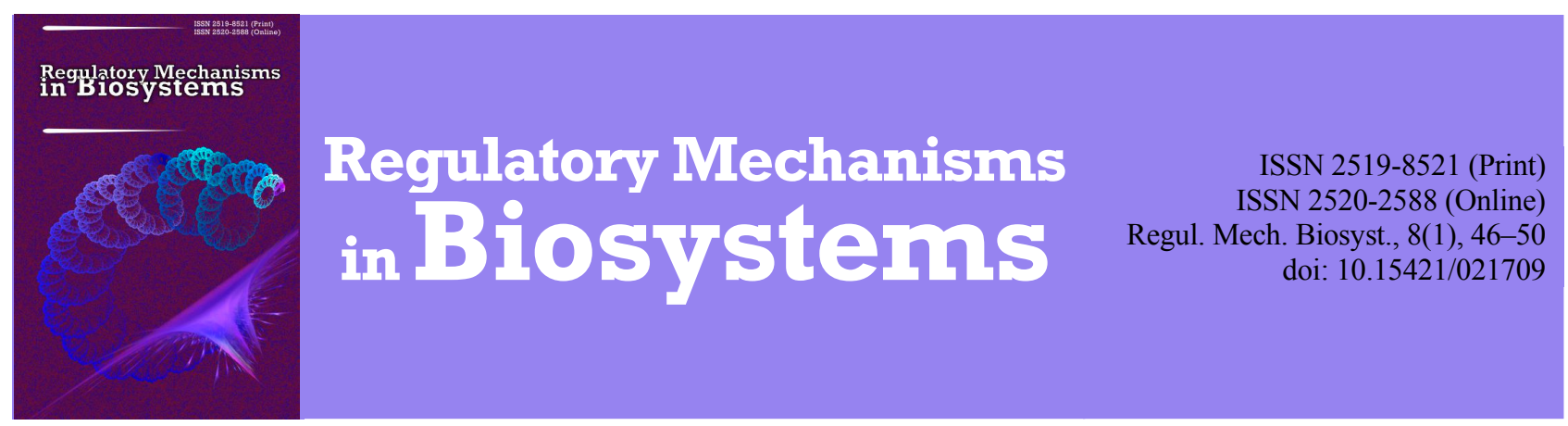

\title{
Pathogenic specifics of development of vegetative dysfunction in adolescents in relation to their morphological status
}

O. Skyba

\author{
Sumy State Pedagogical University named after A. S. Makarenko, Sumy, Ukraine
}

Article info

Received 28.12.2016

Received in revised form 04.02.2017

Accepted 08.02.2017

Sumy State

Pedagogical University named after A. S. Makarenko,

Romenskaya str., 87,

Sumy, 40002, Ukraine

Tel.: +38-066-474-36-74

E-mail: skiba_olga@mail.ua
Skyba, O. (2017). Pathogenic specifics of development of vegetative dysfunction in adolescents in relation to their morphological status. Regulatory Mechanisms in Biosystems, 8(1), 46-50. doi: 10.15421/021709

Exploring the mechanisms of vegetative regulation in children and adolescents of different somatotypes has a prognostic value in regard to the character of adaptive reactions of the organism, as it facilitates the identification of the risk factors of pathological processes and states of vegetative systems, which may cause chronic illness in adulthood. The author defines the pathogenic specifics of development of vegetative dysfunction in adolescents in relation to their morphological status. Cardiointervalography and anthropometric, mathematical and statistical methods of research were used. Based on the results of cardiointervalography, the structure of initial vegetative tonus was established, which was characterized by prevalence of eutonia $(38.4 \pm 4.9 \%)$. The specific weight with background eutonia of adolescent boys and girls tended to be higher among the representatives of the thoracic and muscular somatotypes, compared to adolescents of the alimentive and osseous somatotypes $(\mathrm{P}<0.001-0.05)$. The established specifics indicate that thoracic and muscular somatotypes ensure optimal adaptation of organisms to the environment. Sympathicotonia was measured among the majority of boys of extreme constitutional variants (alimentive and osseous somatotypes) (36.3\% and 30.0\% respectively), which demonstrates the activation of adaptive mechanisms in the abovementioned category of examined adolescents, while among girls this phenomenon was evident among the representatives of the osseous and thoracic somatotypes (38.5\% and 30.8\% respectively). We found that the majority of examined adolescents (53.4\%) had a normal vegetative reactivity. Gender differences in the structure of vegetative reactivity of adolescents could well be explained by the higher number of girls of asympaticotonic type $(19.2 \%)$ compared to boys $(7.3 \%, \mathrm{P}<0.05)$. Furthermore, we found that hypersympathicotonic and asympathicotonic types of vegetative reactivity were characteristic of the majority of representatives of the alimentive and osseous somatotypes irrespective of the gender, which indicates activation of functioning of the cardiovascular system, decreased adaptive capacity of the organism among the examined group. The research shows that the group at risk of developing functional deviations in vegetative systems is formed by the representatives of the alimentive and osseous somatotypes.

Keywords: cardiointervalography; neuroendocrine imbalance; initial vegetative tonus; vegetative reactivity; somatotype

\section{Патогенетичні особливості формування вегетативних дисфункцій у підлітків залежно від їх морфологічного статусу}

\author{
О. О. Скиба
}

\section{Сумський державний педагогічний університет імені А. С. Макаренка, Суми, Украӥна}

Визначено патогенетичні особливості формування вегетативних дисфункцій у підлітків залежно від їх морфологічного статусу. За результатами кардіоінтервалографії визначено структуру вихідного вегетативного тонусу, яка характеризувалась перевагою ейтонії (38,4\%). Встановлено залежність вихідного вегетативного тонусу підлітків від їх морфологічного статусу $\left(\chi^{2}=26,7, \mathrm{P}<0,01\right)$. Питома вага осіб із фоновою ейтонією, як серед хлопців, та і серед дівчат, була вірогідно вищою серед представників торакального та м'язового соматотипів, порівняно з підлітками астеноїдного та дигестивного соматотипів, ( $<0,001-0,05)$. Симпатикотонію визначено серед більшості хлопців крайніх конституційних варіантів (дигестивний та астеноїдний соматотипи) (36,3\% та 30,0\% осіб відповідно), що свідчить про напруження адаптаційних механізмів у визначеного контингенту осіб, тоді як у групі дівчат - серед представників астеноїдного та торакального соматотипів (38,5\% та 30,8\% осіб відповідно). Переважна більшість обстежених підлітків (53,4\%) має нормальну вегетативну реактивність. Статеві відмінності структури вегетативної реактивності підлітків полягали у вірогідно вищій частці дівчат з асимпатикотонічним типом $(19,2 \%)$, порівняно $з$ хлопцями $(7,3 \%, \mathrm{P}<0,05)$. Гіперсимпатикотонічний та асимпатикотонічний типи вегетативної реактивності притаманні переважній більшості представників дигестивного та астеноїдного соматотипів незалежно від статі. Визначено групу підвищеного ризику розвитку функціональних відхилень із боку вегетативних систем, яку формують представники дигестивного та астеноїдного соматотипів.

Ключові слова: кардіоінтервалографія; нейроендокринний дисбаланс; вегетативний тонус; вегетативна реактивність; соматотип 


\section{Вступ}

Показник ефективності державної політики у сфері охорони здоров'я - соціальне благополуччя та стан здоров'я населення країни. Нині одна 3 найгостріших медико-соціальних проблем в Україні - стан здоров'я дітей та підлітків, найчутливіших до несприятливого впливу різних чинників зовнішнього середовища. У вирішенні проблеми збереження та зміцнення здоров'я дитячого населення одна із провідних ролей належить профілактиці як складовій системи охорони здоров'я (Serdjuk et al., 2016). Дитячий організм має підвищений ризик розвитку відхилень у стані здоров'я через наявність критичних періодів росту та розвитку, особливостей обміну речовин, недосконалості адаптаційних механізмів, недорозвиненості імунної та інших систем, що може спричинити зниження активності регуляторних механізмів через їх перенапруження та виснаження внаслідок розвитку патологічних станів (Majdannyk et al., 2014; Reeva, 2015).

Вегетативна нервова система (BНC) - регуляторна ланка у процесі формування адаптаційних і компенсаторних змін в організмі у результаті формування патологічних станів (Petković and Ćojbašić, 2012; Chernyavskikh et al., 2015). Причому практично немає таких патологічних станів, розвиток яких не був би пов'язаний із розладами вегетативної нервової системи (Messina et al., 2013; Brandão et al., 2014; Majdannyk et al., 2014; Bartczaket al., 2016; Huang et al., 2016; Regitz-Zagrosek and Kararigas, 2017). Вегетативна дисфункція, як правило, розвивається на тлі фенотипічних ознак функціонального стану ВНС (ваготонічна або симпатикотонічна іiі спрямованість) (Vejn, 2003; Esler, 2010; Thayer et al., 2010; Nalyotov, 2014; Campos, 2015). Особливе значення в генезі функціональних відхилень діяльності різних органів та систем, зокрема серцево-судинної, ендокринної, травної та інших, належить дисфункціям ВНС i нейроендокринному дисбалансу, що спостерігається в підлітковому віці (Grosu, 2014; Nóbrega et al., 2014; Marongiu and Crisafulli, 2015; Sladek et al., 2015). Саме в цьому віці виникають передумови для розвитку функціональних розладів із боку вегетативних систем, які можуть стати причиною розвитку хронічних захворювань у дорослому віці (Kraus et al., 2013; Ubrich et al., 2016).

Аналіз останніх досліджень і публікацій вказує на те, що кожному з конституційних типів властиві специфічні особливості функціонування нервової, гуморальної, серцево-судинної та імунної систем (Miculic, 2008; Kazakova et al., 2009; Koenig, et al., 2014; Schoen, 2016). Тому вивчення патогенетичних механізмів виникнення дисфункцій ВНС у підлітків різних соматотипів має прогностичне значення перебігу адаптаційних реакцій організму, що дозволить виявляти донозологічні стани та здійснювати ранню профілактику соматичних захворювань, що зумовлює актуальність дослідження (Denefil, 2013; Messina et al., 2013). Мета цього дослідження - визначити патогенетичні особливості формування вегетативних дисфункцій у підлітків залежно від їх морфологічного статусу.

\section{Матеріал і методи досліджень}

У дослідженні брали участь 99 дітей 15-16 років (58 хлопців та 41 дівчина), які навчаються в інноваційних навчальних закладах (гімназіях) м. Суми. Програма дослідження включала антропометричне обстеження, що проводили за загальновизнаними методиками. Визначали тотальні розміри тіла: довжину (ДТ), масу (МТ), окружність грудної клітки (ОГК). Оцінювання соматотипу здійснювали за схемою Штефко - Островського з виділенням чотирьох конституційних варіантів: астеноїдний, торакальний, м'язовий та дигестивний (Shtefko and Ostrovskyj, 1929).

Для оцінювання функціонального стану ВНС досліджували варіабельність серцевого ритму (ВСР) з використанням апаратнопрограмного комплексу «КардіоСпектр» (АТ Солвейг) відповідно до вимог Міжнародного стандарту (Task Force of the European
Society of Cardiology and the North American Society of Pacing and Electrophysiology, 1996) для коротких записів. Проводили аналіз двох категорій ВCP: часовий (Time-Domain Results) та частотний (Frequency - Domain Results). У часовому аспекті оцінювали показники NN - ряд нормальних R-R інтервалів із виключенням екстрасистол; SDNN - стандартне відхилення NN інтервалів; RMSSD - квадратний корінь із середнього значення квадратів різниць величин послідовних інтервалів R-R; pNN50 - відсоток кардіоінтервалів, що відрізняються від сусідніх більше ніж на 50 мс, від загальної кількості кардіоінтервалів; IH - індекс напруження.

У частотній ділянці визначали абсолютні значення показників TF (Total Frequency) - загальної потужності спектра; HF (High Frequency) - потужності високочастотних коливань спектра, яка характеризує дихальний компонент ВСР, пов'язаний із парасимпатичним регулюванням; LF (Low Frequency) потужності низькочастотних коливань спектра, який відображає активність підкіркового вазомоторного центру та пов'язаний із симпатичною ланкою регуляції; VLF (Very Low Frequency) - потужності наднизькочастотних коливань спектра, який відображає активність надсегментарних відділів автономної нервової системи та нейрогуморальний компонент регулювання, LF/HF - коефіцієнт, який відображає баланс вегетативних впливів. Комп'ютерний аналіз включав визначення вихідного вегетативного тонусу: перевага тонусу парасимпатичного (ваготонія) чи симпатичного (симпатикотонія) відділу ВНС, баланс (ейтонія).

Реєстрацію кардіоінтервалограми проводили в горизонтальному положенні (лежачи на спині), у стані відносного спокою у першій половині дня протягом 5 хвилин. Визначення реактивності ВНС здійснювали за допомогою активної ортостатичної проби (Vejn, 2003; Fedorowski and Melander, 2013). Після проведення фонового запису кардіоінтервалограми обстежений без різких рухів набував вертикального положення, в якому проводився повторний запис кардіоінтервалограми.

Оцінку вегетативної реактивності визначали за відношенням $\mathrm{IH}_{2}$ (індекс напруження в ортостазі) до $\mathrm{IH}_{1}$ (індекс напруження у стані відносного спокою) з виділенням нормального, гіперсимпатикотонічного та асимпатикотонічного типів (Мајdannyk et al., 2014).

Статистичну обробку отриманих даних здійснювали за допомогою програми Statistica 8.0 (StatSoft Inc., USA) з визначенням середнього арифметичного $(\mathrm{M})$ та його стандартної похибки (m). Для процентів стандартну похибку (m) розраховували за формулою:

$$
m=\frac{\sqrt{100-p)}}{n}
$$

Для номінальних змінних розраховували взаємозв'язок за таблицями спряженості та критерієм $\chi^{2}$ Пірсона. Відмінності між вибірками у випадках порівняння їх середніх значень, розподілених за нормальним законом, оцінювали за параметричним критерієм Стьюдента (t). Відмінності між вибірками вважали вірогідними за $\mathrm{P}<0,05$.

Дослідження виконане за планом науково-дослідницької роботи кафедри медико-біологічних основ фізичної культури Сумського державного педагогічного університету імені А. С. Макаренка за темою «Фізіолого-гігієнічний супровід здоров'язбережувальної діяльності закладів освіти», № державної реєстрації 0113 U004662.

\section{Результати}

У структурі вихідного вегетативного тонусу переважала фонова ейтонія $(38,4 \pm 4,9 \%)$, яка забезпечує оптимальну адаптацію організму до факторів зовнішнього середовища. Вегетативний баланс, виявлений у більшості осіб, ймовірно пов'язаний із завершенням адаптаційних перебудов і формуванням оптимальної регуляції на визначеному етапі онтогенезу.

Частка осіб із ваготонією становила $32,3 \pm 4,7 \%$ обстежених, причому серед дівчат вона вірогідно вища $(38,2 \pm 7,6 \%)$ порів- 
няно із хлопцями $(19,4 \pm 5,2 \%, \mathrm{P}<0,05)$. Вагусно-холінергічна спрямованість вегетативної регуляції відповідає морфологічній зрілості організму та забезпечує стабілізацію регуляції серцевого ритму за рахунок удосконалення механізмів саморегуляції. Вегетативний тонус $29,3 \pm 4,6 \%$ підлітків характеризується симпатикотонією та відсутністю вірогідних відмінностей між обстеженими особами чоловічої та жіночої статі.

Установлено залежність вихідного вегетативного тонусу підлітків від їх морфологічного статусу $\left(\chi^{2}=26,7, \mathrm{P}<0,01\right)$. Аналіз структури вихідного вегетативного тонусу хлопців залежно від їх соматотипологічних особливостей виявив вірогідну перевагу фонової ейтонії серед осіб торакального $(40,0 \pm$ $6,4 \%)$ та м'язового $(30,0 \pm 6,0 \%)$ соматотипів, порівняно 3 представниками астеноїдного $(10,0 \pm 3,9 \%, \mathrm{P}<0,001-0,01)$ та дигестивного $(20,0 \pm 5,3 \%, \mathrm{P}<0,05)$ соматотипів (рис. 1$)$.

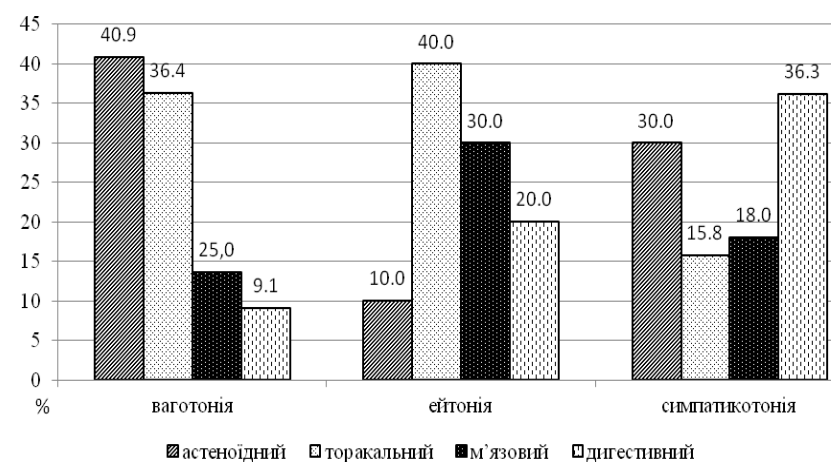

Рис. 1. Структура вихідного вегетативного тонусу хлопців (\%) залежно від соматотипу $(\mathrm{n}=58)$

Частка осіб із ваготонією вірогідно вища серед хлопців астеноїдного, торакального та м'язового соматотипів $(40,9 \pm 6,5 \%$, $36,4 \pm 6,3 \%$ та 25,0 $\pm 5,7 \%$ осіб відповідно), порівняно з підлітками дигестивного соматотипу $(9,1 \pm 2,8 \%, \mathrm{P}<0,001-0,05)$.

Вегетативний дисбаланс, що проявляється симпатикотонією, притаманний більшості підлітків крайніх конституційних варіантів (дигестивний та астеноїдний соматотипи) $(36,2 \pm 6,3 \%$ та $30,0 \pm 6,0 \%$ осіб відповідно), що свідчить про напруження адаптаційних механізмів у визначеного контингенту осіб.

У групі дівчат структура вихідного вегетативного тонусу подібна показникам осіб чоловічої статі, оскільки характеризується вірогідною перевагою ейтонії серед представників торакального $(50,0 \pm 7,8 \%)$ та м'язового $(38,9 \pm 7,6 \%)$ соматотипів, порівняно 3 представниками астеноїдного $(11,1 \pm 4,9 \%$, $\mathrm{P}<0,001-0,01)$ та дигестивного (0\%) соматотипів (рис. 2). Визначені особливості свідчать про те, що торакальний і м'язовий соматотипи забезпечують оптимальну адаптацію організму до факторів навколишнього середовища.

Ваготонічний вихідний вегетативний тонус спостерігається у більшості дівчат м'язового та торакального соматотипів (50,0 $\pm 7,8 \%$ та $30,0 \pm 7,2 \%$ обстежених відповідно), тоді як симпатикотонічний - у дівчат астеноїдного та торакального соматотипів $(38,5 \pm 7,6 \%$ та $30,8 \pm 7,2 \%$ осіб відповідно). Виявлений дисбаланс стану регуляторних систем осіб жіночої статі може бути пов'язаний із нерівномірністю дозрівання регуляторних механізмів на даному етапі онтогенезу.

Інтегральний показник, що відображає ступінь централізації управління серцевим ритмом, - індекс напруженості (IH). В ортостатичному положенні і серед хлопців $(+156,8 \pm 20,0 \%)$, і серед дівчат $(+146,2 \pm 24,1 \%)$ відбувається збільшення $\mathrm{IH},-$ закономірна реакція, яка свідчить про активацію центрального контуру вегетативної регуляції.

Аналіз приросту IH серед хлопців залежно від їх соматотипологічних особливостей свідчить про вірогідно вищі значення IH серед представників дигестивного соматотипу $(+218,8 \pm 66,1 \%)$, порівняно 3 хлопцями м'язового соматотипу $(+91,5 \pm 19,4 \%, \mathrm{P}<0,05)$ (рис. 3).
На фоні загальної тенденції до збільшення ІН у відповідь на ортостаз серед дівчат дигестивного соматотипу відмічене найбільше значення його приросту $(+239,0 \pm 100,5 \%)$ (рис. 3$)$.

За результатами оцінювання вегетативної реактивності встановлено перевагу нормальної вегетативної реактивності $(53,4 \pm$ $5,0 \%$ ), однак частка осіб із гіперсимпатикотонічною реактивністю була високою $(35,6 \pm 4,8 \%$ обстежених), що вказує на підвищення внеску симпатоадреналових впливів у відповідь на ортостаз і свідчить про напруження адаптаційних можливостей організму підлітків. Статеві відмінності структури вегетативної реактивності підлітків полягали у вірогідно вищій частці дівчат з асимпатикотонією $(19,2 \pm 6,3 \%)$ порівняно 3 хлопцями $(7,3 \pm 3,4 \% \mathrm{P}<0,05)$, а гіперсимпатикотонічна реактивність характеризувалась тенденцією до переваги у групі хлопців. Аналіз показників вегетативної реактивності дозволив визначити їх залежність від особливостей морфологічного статусу підлітків $\left(\chi^{2}=34,2, \mathrm{P}<0,001\right)$. Нормальна вегетативна реактивність притаманна більшості представників чоловічої статі торакального $(31,8 \pm 6,1 \%)$ та м'язового $(36,4 \pm 6,3 \%)$ соматотипів (рис. 4). У переважної більшості хлопців визначених соматотипів у структурі вихідного вегетативного тонусу переважала ейтонія (40,0 $\pm 6,4 \%$ та $30,0 \pm 6,0 \%$ відповідно).

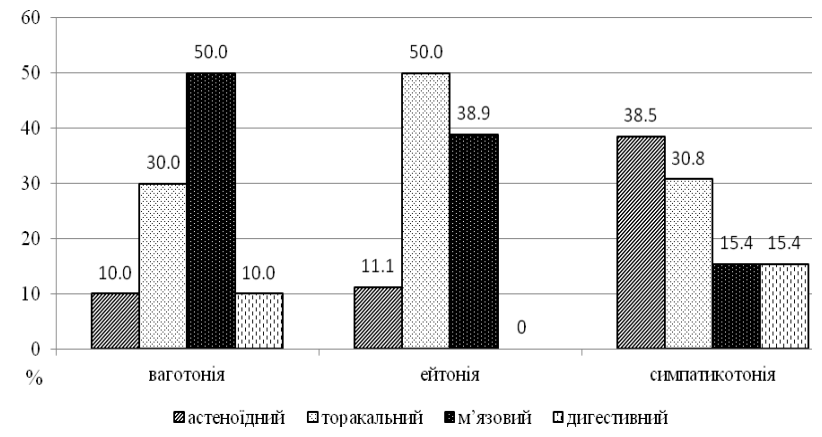

Pис. 2. Структура вихідного вегетативного тонусу дівчат (\%) залежно від їх соматотипу $(\mathrm{n}=41)$

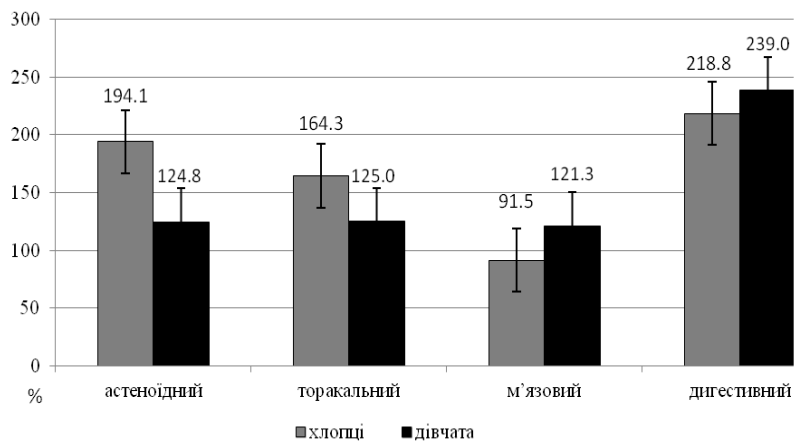

Рис. 3. Приріст значень індексу напруження (\%) у підлітків різних соматотипів у відповідь на ортостаз $(\mathrm{n}=99)$

Асимпатикотонічна реактивність спостерігалась тільки серед підлітків астеноїдного та дигестивного соматотипів (66,7 \pm $6,2 \%$ та $33,3 \pm 6,2 \%$ осіб відповідно), що свідчить про незадовільну адаптацію внаслідок зниження захисно-пристосувальних механізмів їх організму. Вегетативний дисбаланс, що проявлявся гіперсимпатикотонічною реактивністю, визначено серед переважної більшості представників крайніх конституційних типів (дигестивний та астеноїдний соматотипи) $(43,8 \pm$ $6,5 \%$ та $31,3 \pm 9,1 \%$ осіб) на фоні високої вихідної активності симпатичного відділу ВНС, що вказує про напруження функціонування серцево-судинної системи, зниження адаптаційних можливостей організму у визначеного контингенту осіб. Установлені особливості можуть слугувати прогностичним маркером розвитку вегетативних дисфункцій та патології серцевосудинної системи. Структура вегетативної реактивності у групі дівчат подібна до структури групи осіб чоловічої статі: 
нормальна вегетативна реактивність притаманна переважній більшості осіб м'язового та торакального соматотипів (41,2 \pm $7,7 \%$ та $35,3 \pm 7,5 \%$ осіб відповідно), тоді як частка дівчат астеноїдного та дигестивного соматотипів вірогідно нижча (Р<0,05, рис. 5).

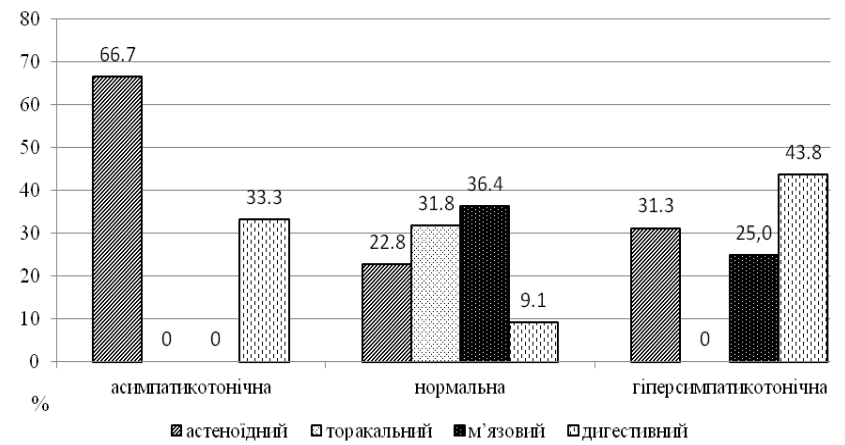

Рис. 4. Структура вегетативної реактивності хлопців (\%) залежно від їх соматотипу $(\mathrm{n}=58)$

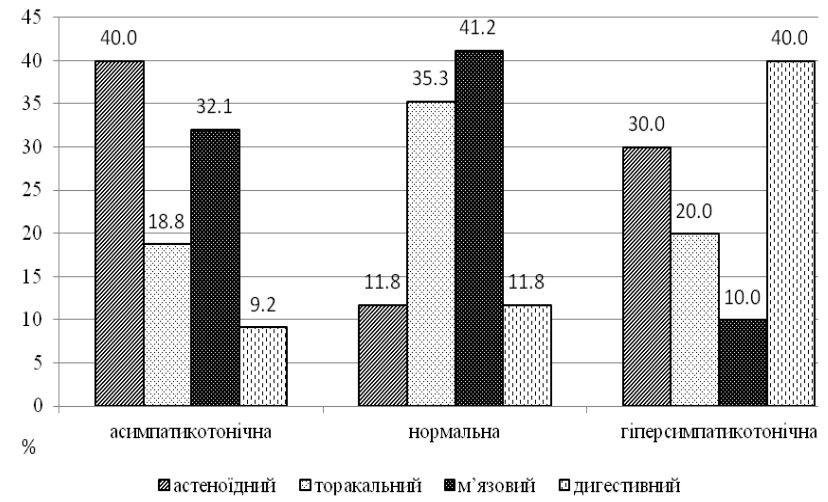

Рис. 5. Структура вегетативної реактивності дівчат (\%) залежно від їх соматотипу $(n=41)$

Збільшення симпатоадреналового впливу та напруження резервних можливостей організму дівчат спостерігали серед більшості осіб дигестивного соматотипу (40,0 \pm 7,7\%). Асимпатикотонічна вегетативна реактивність виявлена серед більшості представників астеноїдного соматотипу (40,0 \pm 7,7\% дівчат), що вказує на нестійкість та зниження у них адаптаційних можливостей організму.

\section{Обговорення}

Визначено перевагу ейтонії та нормальної вегетативної реактивності серед обстежених підлітків на фоні зменшення частки осіб із симпатикотонічним вихідним вегетативним тонусом і гіперсимпатикотонічною реактивністю, що віддзеркалює вікові закономірності їх онтогенетичного розвитку (Majdannyk et al., 2014; Nóbrega et al., 2014; Sladek et al., 2015; Angelovski et al., 2016). У більшості практично здорових підлітків м'язового та торакального соматотипів спостерігається оптимальна взаємодія парасимпатичної та симпатичної ВНС. Менш сприятливими в плані вегетативної регуляції виявляються підлітки 3 дигестивним соматотипом, серед переважної більшості яких визначається депресія парасимпатичного відділу ВНС (Kazakova et al., 2009; Koenig et al., 2014).

Вегетативний дисбаланс, що проявлявся гіперсимпатикотонічним і асимпатикотонічним типами вегетативної реактивності, притаманний більшості представників (як хлопців, так i дівчат) дигестивного та астеноїдного соматотипів, які формують групу підвищеного ризику розвитку функціональних відхилень i3 боку вегетативних систем (Kazakova et al., 2009; Fedorowski and Melander, 2013; Marongiu and Crisafulli, 2015).

\section{Висновки}

Структура вихідного вегетативного тонусу більшості обстежених осіб $(38,4 \pm 4,9 \%)$ характеризувалася перевагою ейтонії. Частка осіб із фоновою ейтонією, як серед хлопців, так і серед дівчат, вірогідно вища серед представників торакального та м'язового соматотипів, порівняно з підлітками астеноїдного та дигестивного соматотипів $(\mathrm{P}<0,001-0,05)$.

У групі хлопців симпатикотонія притаманна більшості підлітків крайніх конституційних варіантів (дигестивний і астеноїдний соматотипи) $(36,3 \pm 6,3 \%$ та $30,0 \pm 6,0 \%$ осіб відповідно), що свідчить про напруження адаптаційних механізмів у визначеного контингенту осіб, тоді як у групі дівчат представникам астеноїдного та торакального соматотипів $(38,5 \pm$ 7,6\% та 30,8 $\pm 7,2 \%$ осіб відповідно).

Серед переважної більшості обстежених підлітків установлено нормальну вегетативну реактивність $(53,4 \pm 5,0 \%$ осіб). Статеві відмінності структури вегетативної реактивності підлітків полягали у вірогідно вищій частці дівчат з асимпатикотонічним типом $(19,2 \pm 6,3 \%)$, порівняно із хлопцями $(7,3 \pm$ $3,4 \%, \mathrm{P}<0,05)$.

Гіперсимпатикотонічний та асимпатикотонічний типи вегетативної реактивності визначені серед переважної більшості представників дигестивного та астеноїднного соматотипів (незалежно від статі), що вказує на зниження адаптаційних можливостей організму підлітків визначених конституційних варіантів. Оцінка показників вегетативної регуляції з урахуванням соматотипологічних особливостей дозволяе виділити групу осіб підвищеного ризику розвитку патологічних станів із боку вегетативних систем і розробити заходи профілактики захворювань та їх ранньої діагностики.

Перспективи подальших досліджень - визначення патогенетичних особливостей розвитку вегетативних дисфункцій у спортсменів за впливу факторів навчально-тренувального процесу.

\section{References}

Angelovski, A., Sattel, H., Henningsen, P., \& Sack, M. (2016). Heart rate variability predicts therapy outcome in pain-predominant multisomatoform disorder. Journal of Psychosomatic Research, 83, 16-21.

Bartczak, D., Szymański, L., Bodera, P., \& Stankiewicz, W. (2016). Psychoneuroimmunological aspects of cardiovascular diseases: A preliminary report. Central European Journal of Immunology, 41(2), 209-216.

Brandão, G. S., Urbano, J. J., Fonsêca, N. T., Apostólico, N., Oliveira, E. F., Perez, E. A., Almeida, R. G., Dias, I. S., Santos, I. R., Nacif, S. R., \& Oliveira, L. V. (2014). Analysis of heart rate variability in the measurement of the activity of the autonomic nervous system: Technical note. Manual Therapy, Posturology \& Rehabilitation Journal, 12, 243-251.

Campos, R. R. (2015). Autonomic dysfunction in renovascular hypertension. Autonomic Neuroscience: Basic and Clinical, 192, 40.

Chernyavskikh, S.D., Rzhevskaya, S. A., Goldayeva, K. A., \& Ponomarchuk, N. V. (2015). Functional capabilities of cardiovascular system of adolescents. Nauchnyj Rezul'tat. Serija Fiziologija, 6, 12-17.

Denefil, O. V. (2013). Pokaznyky kardiointervalografii' u studentiv z riznym vyhidnym typom vegetatyvnoi' reguljacii'. Visnyk Problem Biologii' ta Medycyny, 99, 324-328.

Esler, M. (2010). The 2009 Carl Ludwig lecture: Pathophysiology of the human sympathetic nervous system in cardiovascular diseases: The transition from mechanisms to medical management. Journal of Applied Physiology, 108(2), 227-237.

Fedorowski, A., \& Melander, O. (2013). Syndromes of orthostatic intolerance: A hidden danger. Journal of Internal Medicine, 273(4), 322-335.

Grosu, V. (2014). The research of parameters of cardiac rhythm variability of arterial hypertension in children and adolescents. Romanian Journal of Medical Practice, 9(4), 264-271.

Huang, W. L., Liao, S. C., Yang, C. C., Kuo, T. B., Chen, T. T., Chen, I. M., \& Gau, S. S. (2016). Measures of heart rate variability in individuals with somatic symptom disorder. Psychosomatic Medicine, 79(1), $34-42$.

Kazakova, T. V., Fefelova, V. V., Nikolaev, V. G., \& Ermoshkyna, A. J. (2009). Sravnitel'nyj analiz pokazatelej dejatel'nosti vegetativnoj nervnoj sistemy $\mathrm{v}$ zavisimosti ot pola i tipa teloslozhenija. Bjulleten' SO RAMN, 140, 54-60. 
Koenig, J., Jarczok, M. N., Warth, M., Ellis, R. J., Bach, C., Hillecke, T. K., \& Thayer, J. F. (2014). Body mass index is related to autonomic nervous system activity as measured byheart rate variability - a replication using short term measurements. The Journal of Nutrition, Health and Aging, 18(3), 300-302.

Kraus, U., Schneider, A., Breitner, S., Hampel, R., Rückerl, R., Pitz, M., Geruschkat, U., Belcredi, P., Radon, K., \& Peters, A. (2013). Individual daytime noise exposure during routine activities and heart rate variability in adults: A repeated measures study. Environ Health Perspect, 121(2), 607-612.

Majdannyk, V. G., Smijan, O. I., Bynda, T. P., \& Savel'jeva-Kulyk, N. O. (2014). Vegetatyvni dysfunkcii' u ditej. Sums'kyj Derzhavnyj Universytet, Sumy (in Ukrainian).

Marongiu, E., \& Crisafulli, A. (2015). Gender differences in cardiovascular functions during exercise: A brief review. Sport Sciences for Health, 11(3), 235-241.

Messina, G., Luca, V., Viggiano, An., Ascione, A., Iannaccone, T., Chieffi, S., \& Monda, M. (2013). Autonomic nervous system in the control of energy balance and body weight: Personal contributions. Neurology Research International, 2013, 1-5.

Miculic, P. (2008). Anthropometric and physiological profiles of rowers of varying ages and ranks. Kinesiology, 40 (1), 80-88.

Nalyotov, A. V. (2014). Vegetative dysfunction and way of its correction in children with chronic gastroduodenal pathology. Zdorov'e Rebenka, 54, 56-60.

Nóbrega, A. C. L., O’Leary, D. S., Silva, B. M., Marongiu, E, Piepoli, M. F., \& Crisafulli, A. (2014). Neural regulation of cardiovascular response to exercise: Role of central command and peripheral afferents. BioMed Research International, 2014, 1-20.
Petković, D., \& Ćojbašić, Z. (2012). Adaptive neuro-fuzzy estimation of autonomic nervous system parameters effect on heart rate variability. Neural Computing and Applications, 21(8), 2065-2070.

Reeva, S. V. (2015). Ocenka vegetativnoj reguljacii u lic molodogo vozrasta. Pediatr, 7(3), 70-75.

Regitz-Zagrosek, V., \& Kararigas, G. (2017). Mechanistic pathways of sex differences in cardiovascular disease. Physiological Reviews, 97(1), 1-37.

Schoen, F. J. (2016). Morphology, clinicopathologic correlations, and mechanisms in heart valve health and disease. Cardiovascular Engineering and Technology, 2016, 1-15.

Serdjuk, A. M., Kobljans'ka, A. V., \& Skljarenko, K. A. (2016). Derzhavni cil'ovi programy jak instrument deravnoi' polityky z ohorony zdorov'ja v Ukrajini. Dovkillja ta Zdorov'ja, 78, 4-8.

Shtefko, V. G., \& Ostrovskyj, A. D. (1929). Shema klynycheskoj dyagnostyky konstytucyonal'nyh typov. Gosmedyzdat, Moscow (in Rassian)

Sladek, C. D., Michelini, L. C., Stachenfeld, N. S., Stern, J. E., \& Urban, J. H. (2015). Endocrine-autonomic linkages. Comprehensive Physiology, 5(3), 1281-1323.

Thayer, J. F., Yamamoto, S. S., \& Brosschot, J. F. (2010). The relationship of autonomic imbalance, heart rate variability and cardiovascular disease risk factors. International Journal of Cardiology, 141(2), 122-131.

Ubrich, R., Barthel, P., Berkefeld, A., Hnatkova, K., Huster, K. M., Dommasch, M., Sinnecker, D., Steger, A., Schmidt, G., \& Malik, M. (2016). Electrocardiographic and cardiac autonomic indices - implications of sex-specific risk stratification in women after acute myocardial infarction. Current Pharmaceutical Design, 22(25), 3817-3828.

Vejn, A. M. (2003). Vegetativnye rasstroystva: Klinika, diagnostika, lechenie [Autonomic dysfunction: Clinical features, diagnosis, treatment]. Meditsinskoe Informatsionnoe Agentstvo, Moscow (in Rassian). 